\title{
Angiotensin II and Vasopressin Stimulate Calcium-activated Chloride Conductance in Rat Mesangial Cells
}

\author{
Toshihiro Okuda, Naohide Yamashita, and Kiyoshi Kurokawa \\ Fourth Department of Internal Medicine, University of Tokyo School of Medicine, 3-28 Mejirodai, Bunkyo-ku, Tokyo 112, Japan
}

\begin{abstract}
In an attempt to clarify the mechanisms by which angiotensin II (AII) and arginine vasopressin (AVP) regulate mesangial cell function, we examined the membrane potential change of mesangial cells and found that cells contracted and membrane potential depolarized in response to AII and AVP. The depolarization was associated with decreased input resistance. Ca ionophore A23187 caused similar mesangial cell contraction and depolarization. The reversal potential $(\mathrm{Vr})$ of the depolarization response to AII and AVP was $-29 \pm 3$ and $-25 \pm 7 \mathrm{mV}$ (mean $\pm \mathrm{SD}$ ), respectively. Not only the $\mathrm{Vr}$ of the AII-induced depolarization but also $\mathrm{Vr}$ of the $\mathrm{Ca}$ ionophore-induced response was dependent upon the extracellular $\mathrm{Cl}^{-}$concentration. Further, AII and AVP caused cell contraction and membrane depolarization in $\mathrm{Ca}^{++}$-free medium containing $0.5 \mathrm{mM}$ EGTA. These data suggest the presence of $\mathrm{Ca}^{++}$-activated $\mathrm{Cl}^{-}$channels in the mesangial cells and that $\mathrm{AII}$ and $\mathrm{AVP}$ increase $\mathrm{Cl}^{-}$permeability via an elevation of $\left[\mathrm{Ca}^{++}\right]_{i}$ released from the intracellular organellae.
\end{abstract}

\section{Introduction}

Mesangial cells are located in the intercapillary space in the glomerulus and are rich in contractile fibers $(1,2)$. These characteristics of mesangial cells suggest that the mesangial cell may regulate, through its contraction, the intraglomerular hemodynamics and thus the glomerular filtration rate (GFR) ${ }^{1}(3-5)$. It has been reported that angiotensin II (AII) and arginine vasopressin (AVP) cause mesangial cell contraction (6-9), which suggests that mesangial cell contraction may underlie the regulation of glomerular hemodynamics and ultrafiltration by these peptide hormones (3-5). The effects of AII and AVP on mesangial cells are thought to be mediated by an increase in the concentration of intracellular $\mathrm{Ca}^{++}$ions $\left(\left[\mathrm{Ca}^{++}\right]_{\mathrm{i}}\right)$, since $\mathrm{Ca}^{++}$ ionophore mimics the hormonal effects on mesangial functions including cell contraction and prostaglandin synthesis $(6,10$, 11). Nonetheless, our understanding of the mechanisms of action

A portion of this paper was presented at the Annual Meeting of the American Society of Nephrology, New Orleans, Louisiana, December 15-18, 1985 and appeared in abstract form (1986. Kidney Int. 29:341 A. [Abstr.]).

Received for publication 4 June 1986.

1. Abbreviations used in this paper: AII, angiotensin II; AVP, arginine vasopressin; GFR, glomerular filtration rate; $i$, intracellular, I-V, currentvoltage; $o$, extracellular; TEA, tetraethylammonium; $\mathrm{Vr}$, reversal potential.

J. Clin. Invest.

(C) The American Society for Clinical Investigation, Inc.

0021-9738/86/12/1443/06 \$1.00

Volume 78, December 1986, 1443-1448 of AII and AVP and of the functional role of mesangial cells in regulating the glomerular functions seems hampered by the paucity of the knowledge on the physiological properties of the mesangial cell. To better understand the function of mesangial cells, we examined in the present study the hormonal responses and their mechanisms of action in the cultured mesangial cells by monitoring the electrophysiological characteristics of the cells. We found the presence of $\mathrm{Ca}^{++}$-activated $\mathrm{Cl}^{-}$channels in plasma membranes of the mesangial cells, which leads to membrane depolarization in response to AII and AVP. The presence of this unique ion channel may be of physiological significance in the hormonal regulation of mesangial cell function and of glomerular hemodynamics and ultrafiltration.

\section{Methods}

Isolation of glomeruli and culture of mesangial cells. The glomeruli were isolated from the kidney of the male Wistar rat weighing 100-200 g. Under ether anaesthesia, rats were exsanguinated, and the kidneys were immediately removed and decapsulated. The cortex was excised and minced into small pieces $(\sim 1 \mathrm{~mm})$ under sterile conditions. The mince was pressed through a $250-\mu \mathrm{m}$ sieve and suspended in isotonic saline. The suspension was successively passed through the 177-, 125-, and 53$\mu \mathrm{m}$ sieves and glomeruli were collected on the surface of the $53-\mu \mathrm{m}$ sieve. The methods were essentially the same as described by Venkatachalam and Kreisberg (6) and by Scharschmidt and Dunn (7). The purity of the glomeruli was $>90 \%$ and almost all of them were decapsulated. Taking advantage of the differential growth characteristics of glomerular epithelial and mesangial cells, mesangial cells were obtained by culturing isolated glomeruli at $37^{\circ} \mathrm{C}$ for $3-5 \mathrm{wk}$ in minimal essential medium containing $18 \%$ fetal calf serum and $0.006 \%$ kanamycin under humidified air containing $5 \% \mathrm{CO}_{2}(12,13)$. It has been well established using immunohistological and morphological criteria that most of the cells obtained by this culture technique are mesangial cells $(6,7)$. The observation under phase-contrast microscope revealed that the cells were morphologically similar to the cultured mesangial cells reported by others (6-13), i.e., flat polygonal cells with processes showing multilayer growing. In the present study, we used more than 50 series of the primary culture of mesangial cells between 3 and 5 wk after each glomerular seeding.

Electrophysiological experiments. The membrane potential of the cultured mesangial cells was recorded by the conventional glass microelectrode technique. The electrodes containing $4.0 \mathrm{M}$ potassium acetate with a resistance of 30-50 megaohms (M $\Omega$ ) were used. The electrodes were made by PA- 81 magnet puller (Narishige, Tokyo, Japan) and have the opening size of $\sim 0.7 \mu \mathrm{m}$. The membrane resistance was monitored by applying constant current pulses of $600 \mathrm{~ms}$ with a bridge circuit. Cultured mesangial cells were first treated for 5-10 min with $\mathrm{Ca}^{++}$-free, phosphate buffered saline containing $0.54 \mathrm{mM}$ EDTA and then again incubated for 30-60 min in minimal essential medium containing $18 \%$ fetal calf serum. After this procedure, the cells became round (Fig. $1 a$ ), and were thus suitable for impalement with the microelectrode. Before the electrophysiological study, the medium was changed to the experimental solution. Table I depicts the constituents of the extracellular solutions. In $\mathrm{Cl}^{-}$-deficient medium, $\mathrm{Cl}^{-}$ions were isotonically replaced by methanesulfonate ions, which are impermeable to $\mathrm{Cl}^{-}$channels. Relatively large cells of a diameter $>50 \mu \mathrm{m}$ were examined in the present experiment because the membrane potential of smaller cells tended to 

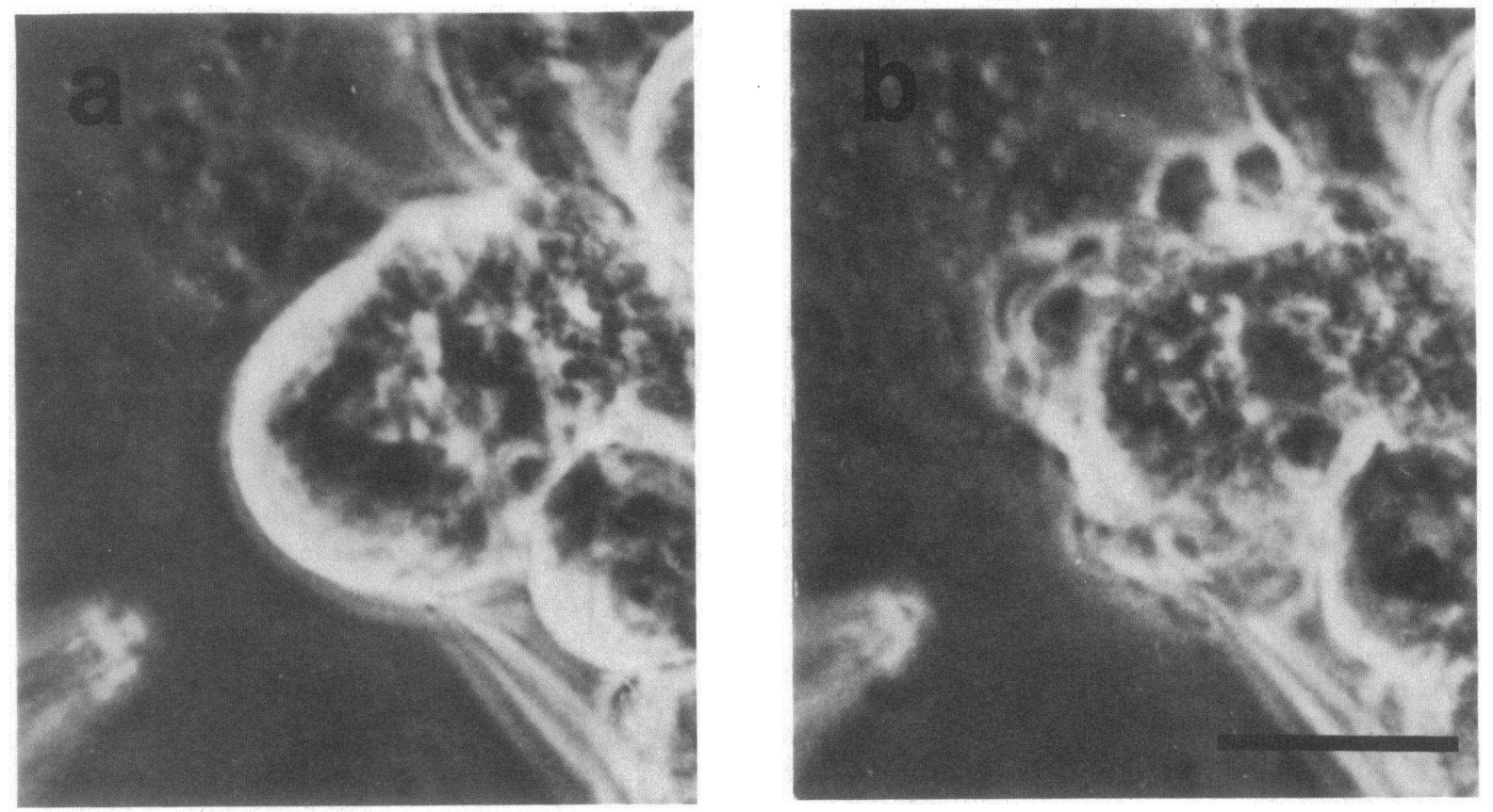

Figure 1. Mesangial cell contraction in response to AII. (a) Mesangial cell after $0.54 \mathrm{mM}$ EDTA preparation. The cell had become rounded and the surface smoothened. The cell was impaled and the glass capillary containing the 100-nM AII was positioned near the cell (lower left). (b) Mesangial cell contracted in response to AII. Bar, $25 \mu \mathrm{m}$.

be unstable after impalement with the electrode. The temperature was kept at $30-32^{\circ} \mathrm{C}$. In some experiments, the extracellular media were exchanged by superfusing the solution using a peristaltic pump.

A glass capillary with a tip diameter of a few microns containing either AII, AVP, or $\mathrm{Ca}^{++}$ionophore (A23187) at concentrations of 100 $\mathrm{nM}, 100 \mathrm{nM}$, and $20 \mu \mathrm{M}$, respectively, was placed $20-30 \mu \mathrm{m}$ apart.from the impaled cell and the agents were delivered to the proximity of the impaled cell by applying positive pressure $\left(0.1-0.2 \mathrm{~kg} / \mathrm{cm}^{2}\right)$ to the inside of the capillary for $1-5 \mathrm{~s}$ if not otherwise noted. To assure that the impaled cell was a mesangial cell, the cell contraction in response to the agents was ascertained simultaneously under phase-contrast microscopy while recording the membrane potential and conductance. The data obtained from the cells that had not shown contraction in response to the agents were discarded.

AII, AVP, and A23187 are purchased from Sigma Chemical Co. (St. Louis, MO). Stock solution of $0.1 \mathrm{mM}$ AII and AVP were prepared in
$100 \mathrm{mM}$ acetic acid and kept frozen until use. A23187 (10 mM) was dissolved in dimethylsulfoxide. These agents were diluted to the final concentration described above by the appropriate experimental solution just before the experiment. The final concentration of acetic acid and dimethylsulfoxide was $0.1 \mathrm{mM}$ and $0.2 \%$, respectively. Contraction or potential change was not observed by administrating the vehicles alone.

Results are expressed as mean \pm SD and analyzed by $t$ test as appropriate.

\section{Results}

Resting potential. The resting potential of mesangial cells in the standard medium was $-53 \pm 7 \mathrm{mV}$ and the input resistance measured by applying hyperpolarizing currents was $47 \pm 24 \mathrm{M} \Omega$ (mean \pm SD: $n=30$ ). The resting potential of the mesangial cells

Table I. Composition of the Experimental Solutions

\begin{tabular}{|c|c|c|c|c|c|c|c|c|c|}
\hline Solution & $\mathrm{Na}$ & $\mathbf{K}$ & $\mathrm{Cl}$ & $\mathrm{Ca}$ & $\mathbf{B a}$ & TEA & TMA & Choline & Methane-sulfonate \\
\hline$m M$ & $m M$ & $m M$ & $m M$ & $m M$ & $m M$ & $m M$ & $m M$ & $m M$ & $m M$ \\
\hline Standard & 151.0 & 6.0 & 140.4 & 1.2 & 0.0 & 0.0 & 0.0 & 0.0 & 0.0 \\
\hline TEA (30) & 121.0 & 6.0 & 140.4 & 1.2 & 0.0 & 30.0 & 0.0 & 0.0 & 0.0 \\
\hline $\mathrm{Ba}(5)$ & 151.0 & 6.0 & 150.4 & 1.2 & 5.0 & 0.0 & 0.0 & 0.0 & 0.0 \\
\hline Na-free & 0.0 & 6.0 & 140.4 & 1.2 & 0.0 & 0.0 & 20.0 & 131.0 & 0.0 \\
\hline Ca-free & 153.4 & 6.0 & 140.4 & 0.0 & 0.0 & 0.0 & 0.0 & 0.0 & 0.0 \\
\hline K (30) & 127.0 & 30.0 & 140.4 & 1.2 & 0.0 & 0.0 & 0.0 & 0.0 & 0.0 \\
\hline K (70) & 87.0 & 70.0 & 140.4 & 1.2 & 0.0 & 0.0 & 0.0 & 0.0 & 0.0 \\
\hline $\mathrm{Cl}(10)$ & 151.0 & 6.0 & 10.0 & 1.2 & 0.0 & 0.0 & 0.0 & 0.0 & 130.4 \\
\hline $\mathrm{Cl}(30)$ & 121.0 & 6.0 & 30.0 & 1.2 & 0.0 & 30.0 & 0.0 & 0.0 & 110.4 \\
\hline $\mathrm{Cl}(60)$ & 121.0 & 6.0 & 60.0 & 1.2 & 0.0 & 30.0 & 0.0 & 0.0 & 80.4 \\
\hline $\mathrm{Cl}(90)$ & 121.0 & 6.0 & 90.0 & 1.2 & 0.0 & 30.0 & 0.0 & 0.0 & 50.4 \\
\hline
\end{tabular}

All solutions contained $1.0 \mathrm{mM} \mathrm{Mg}, 5.5 \mathrm{mM}$ glucose, and $8 \mathrm{mg} / \mathrm{ml}$ bovine serum albumin. pH was adjusted to 7.4 with $20 \mathrm{mM}$ Hepes ( $\mathrm{Na}$ salt in $\mathrm{Na}$-containing solutions and TMA salt in Na-free solutions). In Ca-free solution, $0.5 \mathrm{mM} \mathrm{EGTA-Na} \mathrm{F}_{2}$ was added. TEA, tetraethylammonium; TMA, tetramethylammonium. 


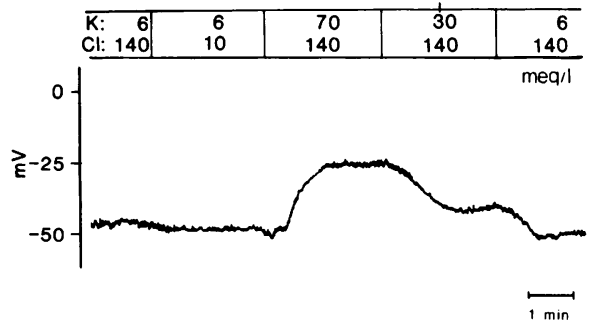

Figure 2. A representative experiment to demonstrate the changes in the resting potential in response to alterations in $\left[\mathrm{K}^{+}\right]$and $\left[\mathrm{Cl}^{-}\right]$in the incubation medium. The media were changed by continuous superfusion. The concentration of $\mathrm{K}^{+}$and $\mathrm{Cl}^{-}$of the medium in meq/liter are depicted in the top panel. Resting potential did not change when $\left[\mathrm{Cl}^{-}\right]_{0}$ was changed from $140 \mathrm{mM}$ to $10 \mathrm{mM}$. When the $\left[\mathrm{K}^{+}\right]_{0}$ was successively changed from 6 to 70,30 , then again to $6 \mathrm{mM}$, the resting potential changed in accordance with $\left[\mathrm{K}^{+}\right]_{\mathbf{o}}$.

was dependent on the extracellular concentration of potassium ions $\left(\left[\mathrm{K}^{+}\right]_{0}\right)$. Fig. 2 exemplifies the changes in the resting potential when the $\left[\mathrm{Cl}^{-}\right]_{0}$ and $\left[\mathrm{K}^{+}\right]_{0}$ were successively changed. The resting potential in the standard medium of this cell was $-50 \mathrm{mV}$. It was depolarized by $24 \mathrm{mV}$ in $70 \mathrm{mM} \mathrm{K}^{+}$medium, and by 10 $\mathrm{mV}$ in $30 \mathrm{mM} \mathrm{K}^{+}$medium, whereas there was no change in the resting potential when $\left[\mathrm{Cl}^{-}\right]_{0}$ was reduced to $10 \mathrm{mM}$. In Fig. 3, the membrane potentials in several cells similarly obtained are plotted against $\left[\mathrm{K}^{+}\right]_{0}$. The resting potential was essentially similar in $\mathrm{Na}^{+}$-free medium (data not shown). The deviation of the resting potential change from the ideal $\mathrm{K}^{+}$electrode as Fig. 3 shows might be caused by nonselective channels or the leakage conductance. However, it is reasonable to state that the resting potential of the mesangial cells was in part determined by $\left[\mathrm{K}^{+}\right]_{0}$ under the present experimental condition.

Steady-state current-voltage relation. The current-voltage (I-V) relation in the standard medium showed an outward-going rectification at the potential levels $>-50 \mathrm{mV}$ (Fig. 4, $a$ and $b$ ). As Fig. 5 shows, the outward-going rectification was suppressed and the $\mathrm{I}-\mathrm{V}$ relation became linear in the presence of either 30 $\mathrm{mM}$ tetraethylammonium (TEA) or $5 \mathrm{mM}$ barium, suggesting that the outward-going rectification was due to $\mathrm{K}^{+}$channels.

Effects of AII. Fig. 6 depicts the representative membrane

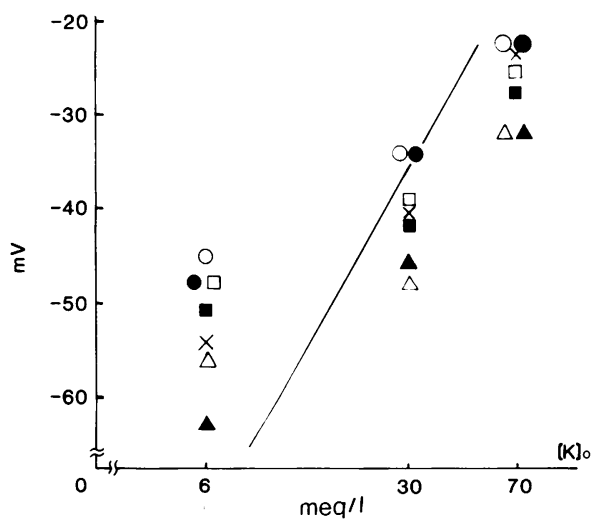

Figure 3. The relationship between the resting potential and $\left[\mathrm{K}^{+}\right]_{0}$. The resting potential on the ordinate at varying $\left[\mathrm{K}^{+}\right]_{\mathrm{o}}$ on the abscissa is shown. Each symbol denotes the data in the same cell recording. The line denotes the theoretical relationship between the resting potential and $\left[\mathrm{K}^{+}\right]_{0}$ calculated from Nernst's equation, assuming that $\left[\mathrm{K}^{+}\right]_{\mathrm{i}}$ is $120 \mathrm{mM}$. a
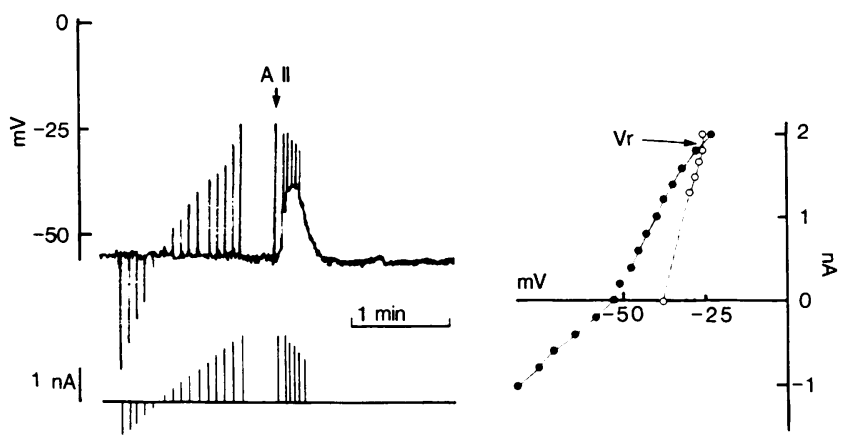

Figure 4. The I-V relationship in the standard medium before and after a 100-nM AII application. (a) The membrane potential response to current pulses of $600 \mathrm{~ms}$ with varying amplitude. $(b)$ The I-V relations of mesangial cell before (solid circles) and at the peak of angiotensin II-induced depolarization (open circles) plotted from the data in $a$. The potential level where the two lines cross $(-26 \mathrm{mV})$ is the $\mathrm{Vr}$ of membrane depolarization.

potential change in the standard medium in response to AII. In response to a brief application of AII, the membrane potential immediately depolarized by $24 \mathrm{mV}$ with a decrease in input resistance. The contraction of mesangial cells, viewed under microscope, began within a minute of AII delivery. Fig. 1, $a$ and $b$ compares the typical morphological change induced by application of AII. The surface of the mesangial cell, which was smooth before the application of the hormone (Fig. $1 a$ ), became irregular and the cell itself shrank in size (Fig. $1 b$ ). This visible change of the cell shape continued for several minutes. The membrane potential changes always preceded the cell contraction viewed under microscope.

Reversal potential ( Vr) of the response. Fig. $4 b$ shows the I-V curves before (solid circles) and at the peak of AII-induced depolarization (open circles) obtained from the data Fig. $4 a$

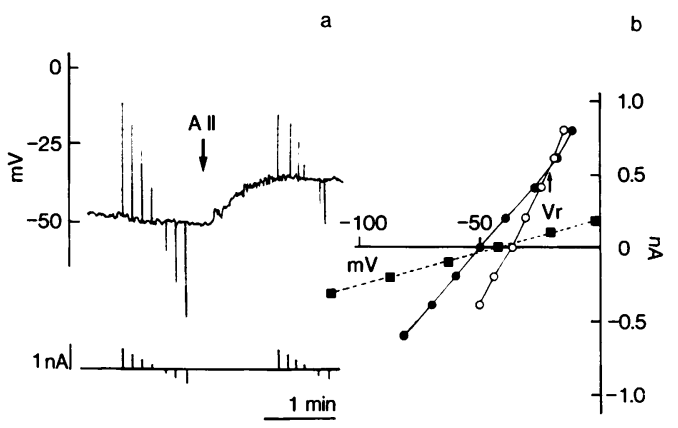

Figure 5. The I-V relationship in the presence of $30 \mathrm{mM}$ TEA and 5 $\mathrm{mM}$ barium, and the response to AII. (a) The membrane potential response to current pulses of $600 \mathrm{~ms}$ with varying amplitude in the presence of $30 \mathrm{mM}$ TEA. At the arrow, AII $(100 \mathrm{nM})$ was given for $5 \mathrm{~s}$ and the membrane potential depolarized. $(b)$ The I-V relations of mesangial cell before (solid circles) and at the peak of AII-induced depolarization (open circles) plotted from the data in Fig. $5 a$. The potential level where the two lines cross $(-22 \mathrm{mV})$ is the $\mathrm{Vr}$ of membrane depolarization. Solid squares with dashed line represents the I-V relation of another cell in the presence of $5 \mathrm{mM}$ barium. The outward-going rectification observed in the standard medium was suppressed and the I-V relation became linear in the presence of $30 \mathrm{mM}$ TEA or $5 \mathrm{mM}$ barium, which suggests that the outward-going rectifcation was due to potassium channels. 


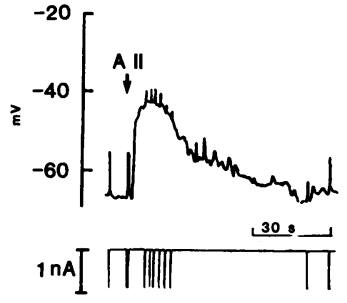

Figure 6. The membrane potential change in response to $100 \mathrm{nM}$ AII in the standard medium. Mesangial cells were incubated in the standard solution and current pulses of $600 \mathrm{~ms}$ with a constant amplitude were applied. The membrane potential depolarized and the input resistance decreased in response to AII.

shows. The potential level where these two I-V curves intercept (arrow in Fig. $4 b$ ), indicates the $\mathrm{Vr}$ of the response to AII, the potential level at which the membrane potential does not change in response to AII. The average of the $\mathrm{Vr}$ thus obtained in the standard solution containing $140 \mathrm{mM} \mathrm{Cl}$ was $-29 \pm 3 \mathrm{mV}$ ( $n$ $=6$, from two cultures). However, in many cells it was difficult to determine accurately the $\mathrm{Vr}$ because the well developed outward-going rectification prevented the recording of the I-V relation at the potential level $>-30 \mathrm{mV}$. In the medium containing $30 \mathrm{mM}$ TEA, the outward-going rectification was suppressed (Fig. 5, $a$ and $b$, solid circles), making it feasible to accurately estimate the I-V relation at any potential. As Fig. 5 shows, the $\mathrm{Vr}$ of the response to AII in the presence of $30 \mathrm{mM}$ TEA can be determined in the similar fashion as in the standard solution, as Fig. 4 shows. The Vr obtained in $30 \mathrm{mM}$ TEA medium containing $6 \mathrm{mM} \mathrm{K}^{+}$was $-27 \pm 3 \mathrm{mV}$ ( $n=6$, from three cultures), a value almost identical to that obtained in the absence of TEA. The result indicates that TEA did not cause an appreciable change in increased ion permeability by AII. Therefore, the subsequent experiments were carried out in the medium containing 30 mM TEA.

Dependence of $\mathrm{Vr}$ on $\left[\mathrm{Cl}^{-}\right]_{o}$. The presence of $\mathrm{Cl}^{-}$channels has been reported in pancreas acinar cells and xenopus oocytes $(14,15)$, which demonstrate an equilibrium potential for $\mathrm{Cl}^{-}$ ions at $\sim-20--30 \mathrm{mV}$. These data suggest that the opening of $\mathrm{Cl}^{-}$channels may account for the membrane depolarization of mesangial cells in response to AII. To test this possibility, the Vr was examined in the medium with varying $\left[\mathrm{Cl}^{-}\right]_{0}$. Fig. 7 depicts the relation between the $\left[\mathrm{Cl}^{-}\right]_{0}$ and $\mathrm{Vr}$ of the membrane depolarization by AII (solid circles). Reduction in $\left[\mathrm{Cl}^{-}\right]_{\mathrm{o}}$ was

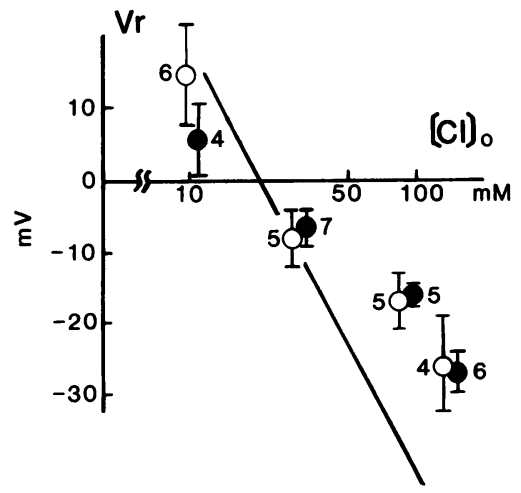

Figure 7. Dependence of the AII (solid circles) and A23187 (open circles) induced $\mathrm{Vr}$ on $\left[\mathrm{Cl}^{-}\right]_{0}$. Each circle with bar denotes the mean $\pm \mathrm{SD}$ and the number by each circle is the number of the cells examined. These cells were obtained in four separate cultures for All study and in additional four cultures for A23187 study. The solid line represents ideal $\mathrm{Cl}^{-}$electrode potential calculated from Nernst's equation, assuming $\left[\mathrm{Cl}^{-}\right]_{\mathrm{i}}$ is $20 \mathrm{mM}$.
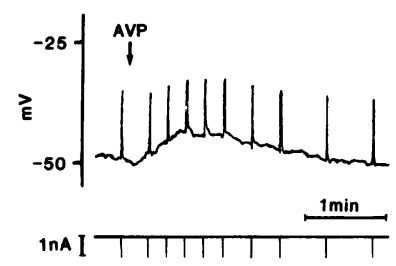

Figure 8. Membrane potential depolarization with decreased input resistance induced by $100 \mathrm{nM}$ TEA and $140 \mathrm{mM} \mathrm{Cl}^{-}$. AVP in the presence of $30 \mathrm{mM}$

associated with less negative $\mathrm{Vr}$, and in $10 \mathrm{mM}\left[\mathrm{Cl}^{-}\right]_{0}$, the $\mathrm{Vr}$ became even positive. The data indicate that the membrane depolarization by AII is mainly caused by an increase in $\mathrm{Cl}^{-}$ conductance. Because the $\mathrm{Vr}$ is slightly deviated from the theoretical equilibrium potential of $\mathrm{Cl}^{-}$ions calculated from Nernst's equation (straight line in Fig. 7), the permeability change to some other ions may also participate in the membrane depolarization.

Effects of AVP. AVP caused contraction and membrane depolarization of mesangial cells, similar to those observed with AII (Fig. 8). The Vr of AVP-induced depolarization in the presence or absence of TEA was $-25 \pm 7 \mathrm{mV}(n=5$, from two cultures). Therefore, the membrane depolarization by AVP was considered to be also caused by an increase in $\mathrm{Cl}^{-}$conductance.

Role of $\mathrm{Ca}^{++}$ions. Available data suggest that an increase in $\left[\mathrm{Ca}^{++}\right]_{\mathrm{i}}$ is an important mediator of the mesangial cell contraction induced by AII and AVP $(6,7)$. Thus, it is possible that an increase in $\left[\mathrm{Ca}^{++}\right]_{i}$ may underlie the membrane potential depolarization. To test this possibility, we examined the effect of Ca ionophore (A23187) on the membrane potential of the mes-

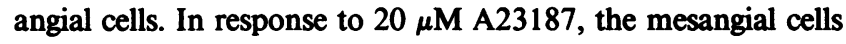
contracted and the membrane potential depolarized with an increased membrane conductance (Fig. 9). The $\mathrm{Vr}$ in $140 \mathrm{mM}$ $\left[\mathrm{Cl}^{-}\right]_{0}$ was $-26 \pm 7 \mathrm{mV}$ ( $n=4$, from one culture), a value almost identical with those by AII and AVP. The Vr of the responses to A23187 (Fig. 7, open circles) was dependent on $\left[\mathrm{Cl}^{-}\right]_{0}$, which was similar to the $\mathrm{Vr}$ with AII. These data strongly suggest that the increased $\mathrm{Cl}^{-}$conductance by AII or AVP was mediated by an increase in $\left[\mathrm{Ca}^{++}\right]_{i}$.

To determine the source of $\mathrm{Ca}^{++}$ions causing a rise in $\left[\mathrm{Ca}^{++}\right]_{i}$ in the response to AII or AVP, the cell contraction and the membrane potential change were examined in $\mathrm{Ca}^{++}$-free medium containing $0.5 \mathrm{mM}$ EGTA where $\mathrm{Ca}^{++}$influx should be negligible. In this medium, the mesangial cell contracted and the membrane potential depolarized in response to AII or AVP. Fig. 10 shows the depolarization and increased membrane conductance in response to AII (100 $\mathrm{nM})$ in the $\mathrm{Ca}^{++}$-free medium containing $0.5 \mathrm{mM}$ EGTA. The Vr of the response to AII in the $\mathrm{Ca}^{++}$-free medium containing $0.5 \mathrm{mM} \mathrm{EGTA}$ and $140 \mathrm{mM} \mathrm{Cl}^{-}$ was $-26 \pm 7 \mathrm{mV}$ ( $n=5$, from two cultures). These data suggest that the cell contraction and the increase in $\mathrm{Cl}^{-}$conductance

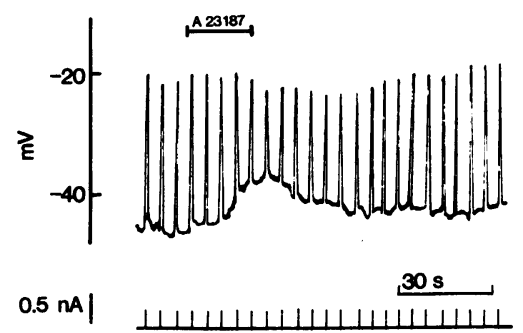

Figure 9. Membrane potential depolarization with decreased input resistance induced by applying $20 \mu \mathrm{M} \mathrm{A23187} \mathrm{for} 20 \mathrm{~s}$. 


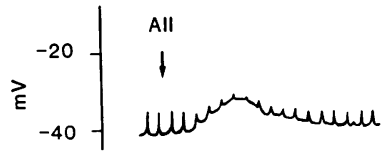

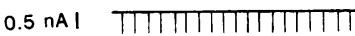

$1 \mathrm{~min}$
Figure 10. Membrane potential depolarization with decreased input resistance induced by $100 \mathrm{nM}$ AII in $\mathrm{Ca}^{++}$-free medium containing $0.5 \mathrm{mM}$ EGTA and $140 \mathrm{mM} \mathrm{Cl}^{-}$. AII was given by applying air pressure for $5 \mathrm{~s}$.

was caused by mobilization of $\mathrm{Ca}^{++}$ions from the intracellular organellae.

\section{Discussion}

The present study has demonstrated that AII and AVP caused the membrane potential depolarization accompanied by an increase in the membrane conductance in the mesangial cells. The membrane depolarization was caused mainly by an increase in $\mathrm{Cl}^{-}$conductance. $\mathrm{Ca}^{++}$ionophore $\mathrm{A} 23187$ similarly increased the membrane conductance to $\mathrm{Cl}^{-}$ions, suggesting that the increased $\mathrm{Cl}^{-}$conductance induced by AII or AVP is mediated by an increase in $\left[\mathrm{Ca}^{++}\right]_{i}$, that is, AII and AVP increase $\mathrm{Ca}^{++}$. activated $\mathrm{Cl}^{-}$conductance. Both the membrane potential depolarization by increasing $\left[\mathrm{K}^{+}\right]_{0}$ to $70 \mathrm{mM}$ (membrane potential depolarized to $-27 \pm 4 \mathrm{mV}[n=6])$ and continuous depolarizing currents failed to induce cell contraction and to increase $\mathrm{Cl}^{-}$ conductance. These data indicate that $\mathrm{Ca}^{++}$influx through voltage-gated $\mathrm{Ca}^{++}$channels may not be involved in $\mathrm{Ca}^{++}$-activated $\mathrm{Cl}^{-}$conductance in mesangial cells. This is in contrast to $\mathrm{Ca}^{++}$ activated $\mathrm{Cl}^{-}$channels reported in other cell types (15-17).

There is some controversy as to whether the effects of AII and AVP on mesangial cells are mediated by $\mathrm{Ca}^{++}$influx from outside the cell or by $\mathrm{Ca}^{++}$released from the intracellular organellae. Scharschmidt and Dunn have reported that enhanced prostaglandin synthesis by AII and AVP was abolished in the absence of extracellular $\mathrm{Ca}^{++}$(7). However, there is a possibility that the intracellular $\mathrm{Ca}^{++}$store may have been depleted in their experiments because the cells were exposed to $\mathrm{Ca}^{++}$-free media as long as for $2 \mathrm{~h}$. In our experiments, mesangial cells were exposed to a $\mathrm{Ca}^{++}$-free environment $<30 \mathrm{~min}$. Venkatachalam and Kreisberg also reported that mesangial cell contraction could be abolished in response to AVP in the $\mathrm{Ca}^{++}$-free solution (6), an observation in contrast to ours. In our present study, mesangial cell contraction and the membrane depolarization in response to AII and AVP were clearly detected and reproduced in $\mathrm{Ca}^{++}$-free medium containing $0.5 \mathrm{mM}$ EGTA. Thus, it seems reasonable to deduce that actions of AII and AVP in mesangial cells are mediated by $\mathrm{Ca}^{++}$release from the intracellular organellae, possibly endoplasmic reticulum. A recent preliminary report by Takeda and Schrier suggests that intracellular $\mathrm{Ca}^{++}$ mobilization initiates the effect of AII on mesangial cell contraction (18), an observation consistent with our postulate.

Results of the present study may suggest that the membrane potential change and cell contraction in response to AII, AVP, and $A 23187$ are causally related. In most experiments, membrane depolarization and cell contraction were both observed in the impaled cells in response to three agents used in the present study. Moreover, membrane depolarization always preceded cell contraction. Therefore, it may be reasonable to deduce that the increased $\mathrm{Cl}^{-}$conductance has some role in regulating cell contraction. However, it is equally possible that both membrane depolarization and cell contraction represent two independent cellular responses initiated by an increase in $\left[\mathrm{Ca}^{++}\right]_{i}$. In this regard, it is of note that the membrane potential depolarization induced by high $\left[\mathrm{K}^{+}\right]_{0}$ did not cause cell contraction as described above. These issues need further investigation.

Based on available information, we would like to postulate that this unique permeability to $\mathrm{Cl}^{-}$ions of the plasma membrane may be important in the tubuloglomerular feedback system, i.e., the regulation of glomerular filtration by distal tubular fluid delivery via macula densa. It has been suggested that a change in the luminal $\mathrm{Cl}^{-}$concentration $\left(\left[\mathrm{Cl}^{-}\right]\right)$at macula densa signals the tubuloglomerular feedback mechanism (19) and that mesangial cell contraction acts as an effector mechanism of the tubuloglomerular feedback (3-5). Between macula densa and the glomerulus, there lie Goormaghtigh cells or lacis cells, interstitial cells morphologically indistinguishable from mesangial cells thus called extraglomerular mesangial cells (20). Mesangial cells are tightly coupled with each other and with Goormaghtigh cells by a gap junction, thus forming a syncytium (21). It is expected that a change in the $\left[\mathrm{Cl}^{-}\right]$in the tubular lumen will alter the $\left[\mathrm{Cl}^{-}\right]$in the absorbate. Because the area surrounding Goormaghtigh cells are neither well perfused with capillaries nor drained with lymph vessels $(20,22)$, it is possible that $\left[\mathrm{Cl}^{-}\right]_{0}$ of these cells may be directly altered by a change in $\left[\mathrm{Cl}^{-}\right]$in the tubular fluid perfusing macula densa. Such a change in $\left[\mathrm{Cl}^{-}\right]_{\mathrm{o}}$ may affect Goormaghtigh cell function, particularly in the presence of AII, which is then transmitted to intraglomerular mesangial cells via gap junction. Further studies will support or refute such a hypothesis. In any events, based on these and other observations (22), the presence of $\mathrm{Cl}^{-}$channels in the mesangial cells might lend support for an important role of $\mathrm{Cl}^{-}$ions as a mediator of the tubuloglomerular feedback.

\section{Acknowledgments}

We thank Dr. Etsuro Ogata for encouragements and Miss Masako Yokokawa for technical assistance.

This work was supported by grants from Ministry of Education of Japan (Nos. 59480197 and 5944052), Ministry of Health and Welfare of Japan (No. 361130167390), and from Adult Disease Clinic Memorial Foundation.

\section{References}

1. Andrews, P. M., and A. K. Coffey. 1983. Cytoplasmic contractile elements in glomerular cells. Fed. Proc. 42:3046-3052.

2. Kreisberg, J. I. 1983. Contractile properties of the glomerular mesangium. Fed. Proc. 42:3053-3057.

3. Dworkin, L. D., I. Ichikawa, and B. M. Brenner. 1983. Hormonal modulation of glomerular function. Am. J. Physiol. 244:F95-104.

4. Ichikawa, I., and B. M. Brenner. 1984. Glomerular actions of angiotensin II. Am. J. Med. 76-5b:43-49.

5. Ichikawa, I. 1982. Direct analysis of the effector mechanism of the tubuloglomerular feedback system. Am. J. Physiol. 243:F447-455.

6. Venkatachalam, M. A., and J. I. Kreisberg. 1985. Agonist-induced isotonic contraction of cultured mesangial cells after multiple passage. Am. J. Physiol. 249:C48-55.

7. Scharschmidt, L. A., and M. J. Dunn. 1983. Prostaglandin synthesis by rat glomerular mesangial cells in culture: effects of angiotensin II and arginine vasopressin. J. Clin. Invest. 71:1756-1764.

8. Kreisberg, J. I., and M. J. Karnovsky. 1983. Glomerular cells in culture. Kidney Int. 23:439-447.

9. Ausiello, D. A., J. I. Kreisberg, C. Roy, and M. J. Karnovsky. 
1980. Contraction of cultured rat glomerular cells of apparent mesangial origin after stimulation with angiotensin II and arginine vasopressin. $J$. Clin. Invest. 65:754-760.

10. Ardaillou, N., J. Hagege, M. P. Nivez, R. Ardaillou, and D. Schlondorff. 1985. Vasoconstrictor-evoked prostaglandin synthesis in cultured human mesangial cells. Am. J. Physiol. 248:F240-246.

11. Schlondorff, D., J. Perez, and J. A. Satriano. 1985. Differential stimulation of $\mathrm{PGE}_{2}$ synthesis in mesangial cells by angiotensin and A23187. Am. J. Physiol. 248:C119-126.

12. Lovett, D. H., J. L. Ryan, and B. Sterzel. 1983. Stimulation of rat mesangial cell proliferation by macrophage interleukin I. J. Immunol. 131:2830-2836.

13. MacCarthy, E. P., A. Hsu, Y. M. Ooi, and B. S. Ooi. 1985. Evidence for a mouse mesangial cell-derived factor that stimulates lymphocyte proliferation. J. Clin. Invest. 76:426-430.

14. Maruyama, Y., and O. H. Petersen. 1983. Voltage clamp study of stimulant-evoked currents in mouse pancreatic acinar cells. Pflugers Arch. 399:54-62.

15. Barish, M. E. 1983. A transient calcium-dependent chloride current in the immature xenopus oocyte. J. Physiol. 342:309-325.

16. Owen, D. G., M. Segal, and J. L. Barker. 1984. A Ca-dependent
$\mathrm{Cl}^{-}$conductance in cultured mouse spinal neurones. Nature (Lond.). 311:567-570.

17. Mayer, M. L. 1985. A calcium-activated chloride current generates the after-depolarization of rat sensory neurones in culture. J. Physiol. 364:217-239.

18. Takeda, K., J. Kim, and R. Schrier. 1986. Effect of angiotensin II (AII) on Ca kinetics and cell contraction in cultured rat mesangial (Ms) cells. Kidney Int. 29:424. (Abstr.)

19. Schnermann, J., D. W. Ploth, and M. Hermle. 1976. Activation of tubulo-glomerular feedback by chloride transport. Pflugers Arch. 362: 229-240.

20. Bucher, O., and E. Reale. 1961. Zur elektronenmikroskopischen Untersuchung der juxtaglomerulaeren Spezialeinrichtungen die Niere. Z. Zellforsch. Mikrosk. Anat. 54:167-181.

21. Taugner, R., A. Schiller, B. Kaissling, and W. Kriz. 1978. Gap junctional coupling between the juxtaglomerular apparatus and the glomerular tuft. Cell Tissue Res. 186:279-285.

22. Schnermann, J., and J. Briggs. 1985. Function of the juxtaglomerular apparatus: local control of glomerular hemodynamics. In The Kidney: Physiology and Pathophysiology. D. W. Seldin, and G. Giebisch, editors. Raven Press, New York. 669-697. 